\title{
Bantuan Dana Bank Dunia dalam Perspektif Pemenuhan Hak-hak EKOSOB; Studi Kasus pada Sektor Pendidikan di Indonesia
}

\author{
Satria Unggul Wicaksana Prakasa \\ Dosen Fakultas Hukum, Universitas Muhammadiyah Surabaya, Surabaya. \\ e-mail: satria@fh.um-surabaya.ac.id.
}

Info Artikel:

| Diterima: 18 Agustus 2018

| Disetujui: 29 Desember 2018

| Dipublikasikan: 31 Desember 2018

\begin{abstract}
The World Bank assistance in the education sector in Indonesia as a developing country faced with an interest in the fulfillment of the right to education in the perspective of Economy, Social, and Culture (ESC) rights for the society. For Indonesia, World Bank assitance must be in line with the national regulation, therefore harmonization into national law is necessary. The World Bank assistance is aimed at accelerating free trade, and the achievement of global education standards for the recipient countries. Thus, the alignment of the education sector with the interests of the economy and the free market may threaten the education rights of Indonesian citizen. This article will focus on the fulfillment of education right in Indonesia. Seeing the facts from the background, the formulation of the problems raised in this legal research are: (1). characteristics of educational assistance by the World Bank for developing countries. (2). Compatibility between World Bank assistance standards with the fulfillment of ESC rights in education in Indonesia. The purpose of this research is to analyze the characteristics of educational assistance by the World Bank for the third world countries and the suitability of the World Bank assistance to the fulfillment of ESC rights in education in Indonesia. This article based on the normative legal research method, and employs the statute and conceptual approach. It is found two results. First, the World Bank assistance to the education sector has been implemented in several countries, including Indonesia. The fulfillment of the right to education in developing countries have been experiencing an intervention and support from the World Bank. The World Bank asisstence is aim at achieving the goal of education, and to ensure the aid has been allocated for education projects, and to provide students with global education standards. Second, by employing the SABER standard with 4-a method to measure the suitability of the World Bank assistance in the fulfillment of the right to education in Indonesia, it is found that there remain a problem in the 'acceptability' standard. The World Bank should give more weights to the local wisdoms when providing asisstence in the recipient country.
\end{abstract}

Key Worlds: World Bank, Fund Assistance, ESC Rights

\begin{abstract}
Abstrak
Bantuan Bank Dunia di sektor pendidikan di Indonesia sebagai salah satu negara berkembang berhadapan dengan kepentingan dalam pemenuhan hak atas pendidikan dalam perspektif hak ekonomi, sosial, dan budaya (EKOSOB) bagi masyarakat. Tujuan dari penelitian ini adalah untuk menganalisis karakteristik bantuan pendidikan oleh Bank Dunia bagi negara dunia ketiga dan kesesuaian standar bantuan Bank Dunia dengan pemenuhan hak EKOSOB di bidang pendidikan di Indonesia. Melihat fakta-fakta dan latar belakang diatas, maka rumusan masalah yang diangkat pada penelitian hukum ini adalah: (1). karakteristik bantuan pendidikan oleh Bank Dunia bagi negara dunia ketiga. (2). Kesesuaian standar bantuan Bank Dunia dengan pemenuhan hak EKOSOB di bidang pendidikan di IndonesiaMetode penelitian yang digunakan adalah yuridis normatif dengan statute approach dan conceptual approach. Hasil penelitian pertama adalah bantuan Bank Dunia pada sektor pendidikan di beberapa negara termasuk Indonesia, bahwa pemenuhan hak pendidikan di negara-negara berkembang perlu mendapatkan intervensi dan dukungan dari Bank Dunia sendiri dalam rangka mencapai tujuan dari pelayanan pendidikan, serta memastikan dana bantuan yang diberikan telah dikerjakan dalam proyek-proyek pendidikan yang tepat sasaran untuk mewujudkan peserta didik dengan standart pendidikan global. Hasil penelitian kedua adalah antara SABER dengan metode 4-a dalam mengukur kesesuaian bantuan Bank Dunia dalam pemenuhan hak atas pendidikan secara keseluruhan sesuai, kecuali pada aspek acceptability karena standart global pendidikan Bank Dunia tidak memperhatikan aspek kearifan lokal masing-masing negara penerima.
\end{abstract}

Kata Kunci: Bank Dunia, Bantuan Dana, Hak Atas Pendidikan, Hak EKOSOB. 


\section{A. PENDAHULUAN}

Indonesia merupakan negara demokrasi yang menjunjung tinggi hak asasi manusia (HAM), khususnya hak atas pendidikan yang merupakan bagian dari hakhak ekonomi, sosial, dan budaya (EKOSOB). Hak tersebut merupakan suatu konsensus yang berlaku bagi seluruh masyarakat internasional untuk memperhatikan aspek kesejahteraan (prosperity) bagi setiap individu agar menjadi tanggung jawab semua pihak, khususnya negara. ${ }^{1}$

Dimasukkannya hak pendidikan sebagai suatu hak dasar didalam konstitusi UUD 1945 memberi tanggung jawab pemerintah untuk memenuhinya, karena salah satu komponen kemajuan negara dapat dilihat dari sejauh mana hak pendidikan yang berkualitas dan merata serta aksesibel dapat dinikmati oleh masyarakat Indonesia. Ketika masyarakat memiliki bekal pendidikan yang memadai maka kemandirian dalam aspek ekonomi, sosial, politik, meningkatkan ketrampilan akan terwujud. Satu upaya paling penting untuk mengatasi problematika masyarakat, seperti: kemiskinan, buta huruf, pengangguran, gizi buruk, dan sebagainya. ${ }^{2}$ Agar hak tersebut dapat terpenuhi, maka dibutuhkan Anggaran dan Pendapatan Belanja Negara (APBN) yang memadai, selain dari pendapatan dalam negeri melalui pajak maupun non-pajak, Indonesia membutuhkan donor bantuan dana luar negeri.

Bank Dunia merupakan institusi pemberi bantuan dana luar negeri dengan berbagai macam program. Selain memberi pinjaman lunak, juga memberikan bantuan donor moneter berdasarkan ketentuan The Bretton Woods Agreement 1944. Salah satu sektor yang mendapatkan perhatian Bank Dunia adalah pada sektor pendidikan. Wujud perhatian terhadap sektor pendidikan

\footnotetext{
${ }^{1}$ Manissuli Ssenyonjo, et.al., International human Right Law; Six Decades after the UDHR and Beyond, Ashgate Publishing, Burlington, 2010, h. 49-50.

2 Jorge Saavedra, Education financing developing countries: level and sources of funds, The World Bank Press, Washington DC, 2002, h. 1-2
}

dituangkan dalam program "The Education for All (EFA) movement" yang telah disahkan pada 1990. Tujuan khusus dari EFA adalah memberikan bantuan pendidikan dasar bagi negara berkembang di dunia. ${ }^{3}$

Bagi Indonesia, bantuan yang diberikan oleh Bank Dunia diharuskan untuk mengikuti ketentuan Bank Dunia, misalkan harmonisasi dalam regulasi hukum nasional. ${ }^{4}$ Salah satu contoh harmonisasi regulasi hukum sesuai dengan ketentuan Bank Dunia dapat ditemui didalam Undang-Undang Nomor 33 tahun 2003 tentang Alokasi Keuangan Antara Pemerintah Pusat dan Pemerintah Daerah dan Peraturan Pemerintah Nomor 55 tahun 2005 tentang Dana Perimbangan. ${ }^{5}$

Bantuan dana Bank Dunia yang disebut block grant didalam Undang-Undang Nomor 33 tahun 2003 dan Peraturan Pemerintah Nomor 55 tahun 2005, pengalokasiannya diatur melalui Dana Alokasi Umum (DAU) serta Dana Alokasi Khusus (DAK), dimana peruntukkannya harus mengikuti ketentuan-ketentuan yang dipersyaratkan oleh Bank Dunia, yaitu tidak diperbolehkannya alokasi dana untuk insentif, biaya perjalanan, biaya penelitian bagi guru. Bagi Bank Dunia, hal tersebut tidak relevan terhadap peningkatan mutu pendidikan. ${ }^{6}$ Dana bantuan dalam sektor pendidikan tersebut hanya boleh dialokasikan untuk beasiswa bagi peserta didik dan pembangunan sekolah yang sering disebut Bantuan Operasional Sekolah (BOS), serta peningkatan Indeks

\footnotetext{
3 Independent Evaluation Group, From Schooling Access to Learning Outcomes; an Unfinished Agenda, The World Bank Press, Washington DC, 2006, h. 1

4 Steven J. Kless, et.al., The World Bank and Education; Critiques and Alternatives, Sense Publisher, Roterdam, 2012, h. 3-5.

${ }^{5}$ Bank Dunia, Assessing the Role of the School Operational Grant Program (BOS) in Improving Education Outcomes in Indonesia (Report No: AUS4133), The World Bank Office Indonesia, Jakarta, 2014, h.16-18

${ }^{6}$ Bank Dunia, Spending more or spennding better: Improving Education financing in Indonesia (Report No: 73050-ID), The World Bank Office Indonesia, Jakarta, 2013, h. 60-64.
} 
Pembangunan Manusia (IPM) bagi siswa saja. $^{7}$

Salah satu upaya dari Bank Dunia untuk mempercepat perdagangan bebas dan pencapaian standar pendidikan global bagi negara penerima bantuan, maka penyelarasan sektor pendidikan dengan kepentingan ekonomi seperti kompetensi lulusan dan pendidikan vokasi. ${ }^{8}$ Sumbangsih dari sektor pendidikan ini juga diharapkan berdampak atas pembangunan sumber daya manusia (human resources). Permintaan atas pemenuhan lapangan kerja (skilled labour) yang merupakan salah satu komponen untuk semakin mempermudah liberalisasi ekonomi di negara penerima bantuan tersebut. ${ }^{9}$

Selain itu, Bank Dunia yang memiliki fokus bantuan dana terhadap negara-negara berkembang dalam membangun kondisi pendidikan lebih baik, setidaknya dari berbagai program bantuan pendidikan yang diberikan oleh Bank Dunia membuat negaranegara penerima yang merupakan mayoritas negara berkembang bergantung. Bank Dunia dapat membuat kebijakan pendidikan yang bersifat universal sesuai dengan standar standar yang telah dibuat, hal tersebut merupakan upaya yang dilakukan Bank Dunia dalam mewujudkan pemenuhan hak-hak EKOSOB bagi negara penerima bantuan. ${ }^{10}$

Persoalan pemenuhan hak pendidikan yang merupakan satu bagian dari hak-hak EKOSOB masih mengalami kesenjangan dan menjadi persoalan yang berlarut-larut dan belum ada upaya untuk pemenuhannya. Fakta-fakta tersebut menjadi dasar untuk diangkat dalam penelitian hukum ini, dalam rangka menemukan solusi hukum mengenai bantuan dana oleh Bank Dunia kepada Indonesia apakah merugikan atau menguntungkan, khususnya dalam posisi

\footnotetext{
${ }^{7}$ Bank Dunia, Assesing the Role......,Op.cit. h.16-18

8 Phillip W. Jones, World Bank; Financing of Education: Lending, Learning, and Development, Routledge, New York, 2007, h. 1-2.

${ }^{9}$ Bank Dunia, Priorities and Strategies for Education, The World Bank Press, Washington DC, 1995, h. 1-2

${ }^{10}$ Steven J. Kless, et.al., Op.Cit. h. 48-50.
}

Indonesia sebagai negara berkembang, perlu mempertimbangkan dampak dari pemberian bantuan dana oleh Bank Dunia terhadap kedaulatan Indonesia, khususnya dalam merumuskan dan mengesahkan kebijakan pendidikan yang sesuai dengan kebutuhan dan tetap memperhatikan kearifan lokal masyarakat Indonesia.

Melihat fakta-fakta dan latar belakang diatas, maka rumusan masalah yang diangkat pada penelitian hukum ini adalah: (1). karakteristik bantuan pendidikan oleh Bank Dunia bagi negara dunia ketiga. (2). Kesesuaian standar bantuan Bank Dunia dengan pemenuhan hak EKOSOB di bidang pendidikan di Indonesia.

\section{B. METODE PENELITIAN}

Metode penelitian dalam penelitian hukum ini untuk mengetahui bantuan Bank Dunia dalam sektor pendidikan di Indonesia sesuai dengan pemenuhan hak-hak EKOSOB dengan menggunakan pendekatan statute approach. Suatu pendekatan dalam penelitian hukum sebagai suatu proses menemukan aturan hukum, prinsip-prinsip hukum secara doktrinal guna menjawab isu hukum yang sedang diangkat. Pendekatan ini beranjak dari regulasi hukum baik dalam aspek hukum internasional maupun hukum nasional baik bersifat vertikal maupun horizontal, untuk mengkaji aturan hukum yang sejajar atau yang bersifat hierarkis. ${ }^{11}$

Melalui pendekatan konseptual (conceptual approach) dengan melakukan analisis terkait kompatibelitas antara bantuan Bank Dunia dalam sektor pendidikan dengan perspektif pemenuhan hak-hak EKOSOB yang menjadi dasar pemberian bantuan dana tersebut berdasarkan doktrin dan pandangan para ahli serta pandangan konseptual dan teoritis, hal ini bertujuan untuk memecahkan isu hukum yang diajukan tidak hanya dengan pendekatan perundang-undangan semata yang bersifat terbatas. ${ }^{12}$

\footnotetext{
${ }^{11}$ Peter Mahmud Marzuki, Penelitian hukum, Kencana Prenada Group, Jakarta, 2005, h. 96-101.

12 Ibid, h.137-140.
} 


\section{KERANGKA KONSEPTUAL}

1. Karakteristik Bantuan Pendidikan Oleh Bank Dunia Bagi Negara Dunia Ketiga

Bank Dunia didirikan pasca Perang

Dunia ke-II (PD II), dimana kondisi perekonomian dan moneter masyarakat internasional porak poranda, maka perlu ada lembaga moneter internasional yang bertugas memberikan pinjaman keuangan khususnya terkait aspek pemulihan kembali kondisi perekonomian pasca PD II, hal ini tertuang dalam The Bretton Woods Agreement 1944. Salah satu bagian dari Bank Dunia yang melakukan kegiatan pinjaman lunak (soft loan) untuk membangun kondisi perekonomiannya yang terpuruk dengan nama afiliasi yaitu International Bank for Reconstruction and Development (IBRD). Bersama lembaga-lembaga moneter keuangan lainnya seperti International Monetary Found (IMF), dan International Trade Organizations (ITO), ${ }^{13}$ telah melakukan kerja-kerja pembangunan perekonomian internasional. Bank Dunia dibentuk pada Juli 1944 di Kota Bretton Woods. New Hampshire, Amerika Serikat, dimana perjanjian The Bretton Woods Agreement 1944 ditandatangani oleh 45 negara.

Berkaitan dengan pemenuhan hak atas pendidikan, Bank Dunia sepakat bahwa memberikan bantuan kepada negara dunia ketiga berarti telah mendorong negara-negara tersebut untuk lebih maju, hal ini ditandai pada tahun 1953 melalu The Bank's seventh annual report yang membahas mengenai standar minimum dari pemenuhan hak pendidikan yang bertujuan untuk memberikan pendampingan dalam sumber daya manusia yang akan menjalankan program bantuan dana tersebut. Pada tahun 1950, The Bank's Economic Reporting System telah mengindikasi para peminjam dengan keadaan dan kesiapan nasional negara penerima

${ }^{13} \mathrm{IMF}$, History of Bretton Woods Agreement 1944; Cooperation and Recostruction (1944-71), Washington DC, 2008, pada https://www.imf.org/external/about/histcoop.htm, diakses pada 10 Agustus 2018. bantuan tersebut. Pada 1956, The General Conference of UNESCO, mengadopsi "Colombian-Sponsored Resolution" yang meminta Bank Dunia untuk memberikan bantuan lunak dan membiayai pembangunan baik fisik maupun non-fisik dari sekolah dan perguruan tinggi.

Target dari Bank Dunia dalam rangka pemenuhan hak pendidikan bagi anak-anak (primary education) yang dikenal dengan program World Bank Group's Education Strategy 2020 is Learning for All. ${ }^{14}$ Hal tersebut bertujuan agar anak-anak usia sekolah mendapatkan ilmu dan keterampilan dari sekolah yang merupakan tanggung jawab negara untuk memenuhinya sebagai kebutuhan dasar, termasuk berkaitan dengan kesehatan, kebutuhan produktif, menciptakan peluang kerja setelah peserta didik lulus dari sekolah, dan berkontribusi secara sosial.

\section{Perbedaan Pengertian Bantuan (Grant) Serta Pinjaman (Loan) Dana Pendidikan}

Perbedaan dan implikasi hukum yang signifikan dari bantuan (grant) dengan pinjaman (loan) terkait dengan dana Bank Dunia memiliki perbedaan konsekuensi hukum namun juga memiliki persamaan dalam beberapa aspek. Jika bantuan dan pinjaman memiliki perbedaan terkait syarat jaminan, waktu pengembalian dari dana yang dipinjam, platform dana yang dapat dipinjam, serta memiliki akibat hukum bagi Negara yang telat dalam pembayaran pinjaman. ${ }^{15}$

Sedangkan persamaan dari bantuan dan pinjaman adalah peruntukan dana yang diberikan oleh Bank Dunia untuk proyekproyek infrastruktur, percepatan perkembangan kemanusiaan, dan serta proyek-proyek yang berkaitan dengan percepatan perdagangan bebas, juga berkaitan dengan prasyarat lainnya yaitu melakukan harmonisasi hukum dan kebijakan sesuai dengan ketentuan yang diatur oleh Bank Dunia. Tujuannya, agar proyek-proyek yang

\footnotetext{
${ }^{14}$ Bank Dunia, Achieving the Learning For All, The World Bank Press, New York, 2013, h.1-2.

${ }^{15}$ Phillip W. Jones, Op.Cit, h. 4-5
} 
didanai oleh Bank Dunia khususnya pada sektor pendidikan dapat tercapai sesuai kesepakatan bersama yang ditentukan antara Bank Dunia dengan negara penerima bantuan maupun pinjaman moneter. ${ }^{16}$

\section{Alasan Hak Atas Pendidikan Menjadi Bagian dari Hak EKOSOB}

Alasan mengapa hak atas pendidikan yang dilindungi dari mekanisme hukum internasional ternyata mengandung konsepsi filosofis HAM, terutama mengenai hak EKOSOB. Menurut Douglas Ray dan Norma Bernstein Tarrow, secara historis bahwa dimulainya secara hukum internasional mengenai penghormatan HAM adalah pasca Perang Dunia II, dimana dari peristiwa tersebut masyarakat internasional sadar bahwa penghormatan terhadap hak individu untuk menentukan nasibnya sendiri secara merdeka, berkeadilan dan tanpa diskriminasi menjadi perhatian utama. ${ }^{17}$

Perlunya melakukan identifikasi hak atas pendidikan sebagai salah satu bagian dari hak-hak EKOSOB berangkat dari hak atas pendidikan dapat dikategorikan sebagai upaya pemberdayaan bagi masyarakat yang bermartabat, artinya disini bahwa untuk menentukan kemajuan suatu negara dapat dilihat dari bagaimana hak atas pendidikan ini betul-betul menjadi perhatian pemerintah dari negara tersebut untuk pemenuhan hak-hak atas pendidikan tersebut. ${ }^{18}$

Didalam Komentar Umum ke-13 Kovenan EKOSOB menyatakan bahwa alasan utama mengapa hak atas pendidikan sebagai salah satu bagian dari hak EKOSOB karena pendidikan merupakan salah satu instrumen untuk merealisasikan kesejahteraan masyarakat. Karena, melalui pendidikan menjadi sarana utama bagi orang dewasa dan

\footnotetext{
${ }^{16}$ Steven J. Kless et.al, Economy, Aid, and Education, Sense Publisher, Rotterdam, 2013, h. 16-18

${ }^{17}$ Norma Bernstein Tarrow, et.al, Human Rights and Education, Pergamon Press, Oxfordshire, 1987, h. 8.

18 Joel Spring, The Universal Right to Education; Justification, Definiton, and Guidelines, Lawrence Erlbaum Associates, inc., London, h. 28-29.
}

anak-anak yang secara ekonomi dan sosial dimarjinalkan mampu mengangkat diri sendiri keluar dari kemiskinan dan memperoleh cara untuk turut terlibat dalam pembangunan negaranya. ${ }^{19}$

Selain itu, peranan penting untuk memberdayakan perempuan, melindungi anak-anak dari eksploitasi kerja dan seksual yang berbahaya, mempromosikan HAM dan demokrasi, melindungi lingkungan hidup, dan mengendalikan pertumbuhan populasi. Pendidikan semakin dikenali sebagai salah satu investasi finansial yang paling baik dan tersedia bagi negara, walau makna pendidikan tidak sekadar praktis dan instrumental. Pikiran yang cerdas, aktif, dan mampu untuk tidak terkekang dan merdeka merupakan salah satu penanda terpenuhinya HAM yang dimiliki oleh individu tersebut. ${ }^{20}$

Dimasukkannya hak atas pendidikan yang menjadi satu bagian dari hak-hak EKOSOB tidak dalam artian selaras dalam aspek regulasi hukum dalam hukum internasional kepada hukum nasional, akan tetapi bagaimana komitmen negara dan seluruh elemen masyarakat untuk memberikan peluang dan akses pendidikan yang setara serta tanpa diskriminasi, memberikan kesejahteraan dan peningkatan sumber daya manusia (SDM) bagi guru, serta perbaikan infrastruktur dan sarana prasarana, dimana komitmen kuat dari itu semua diformalkan kedalam regulasi hukum dan kebijakan-kebijakan mengenai hak atas pendidikan, hal-hal tersebut menjadi prasyarat penting indikator pembangunan SDM suatu negara.

\section{PEMBAHASAN}

\section{Tujuan Diberikannya Bantuan Dana Bank Dunia}

Berdasarkan Pasal 1 The IBRD Agreement menyatakan baik dari pinjaman lunak maupun hibah/bantuan dari Bank Dunia

19 Komnas HAM RI, Komentar Umum Kovenan Internasional (Terjemahan Dalam Bahasa Indonesia), Komnas HAM, Jakarta, 2009, h.155.

${ }^{20}$ Ibid 
kepada negara-negara penerima semata-mata untuk:

(a) Pembangunan negara-negara anggota;

(b) Mempercepat perkembangan investasi asing, hanya kepada tujuan dan kepentingan produktif pinjaman;

(c) Bantuan tersebut diberikan, memperlancar perkembangan perdagangan internasional;

(d) Dana yang diberikan hanya untuk kebutuhan negara yang mendesak;

(e) Memperhatikan dampak penanaman modal asing dan kondusifitas perekonomian pada negara-negara anggotanya.

\section{Analisis Regulasi Bantuan Pendidikan Menurut Bank Dunia}

Berdasarkan Article V Section 1 IDA Agreement mengenai syarat dan ketentuan penggunaan dana yang merupakan pemberian hibah Bank Dunia menjelaskan bahwa:

(a) The Association shall provide financing to further development in the less-developed areas of the world included within the Association's membership.

(b) Financing provided by the Association shall be for purposes which in the opinion of the Association are of high developmental priority in the light of the needs of the area or areas concerned and, except in special circumstances, shall be for specific projects.

(c) The Association shall not provide financing if in its opinion such financing is available from private sources on terms which are reasonable for the recipient or could be provided by a loan of the type made by the Bank.

(d) The Association shall not provide financing except upon the recommendation of a competent committee, made after a careful study of the merits of the proposal. Each such committee shall be appointed by the Association and shall include a nominee of the Governor or Governors representing the member or members in whose territories the project under consideration is located and one or more members of the technical staff of the Association. The requirement that the committee include the nominee of a Governor or Governors shall not apply in the case of financing provided to a public international or regional organization.

(e) The Association shall not provide financing for any project if the member in whose territories the project is located objects to such financing, except that it shall not be necessary for the Association to assure itself that individual members do not object in the case of financing provided to a public international or regional organization.

(f) The Association shall impose no conditions that the proceeds of its financing shall be spent in the territories of any particular member or members. The foregoing shall not preclude the Association from complying with any restrictions on the use of funds imposed in accordance with the provisions of these Articles, including restrictions attached to supplementary resources pursuant to agreement between the Association and the contributor.

(g) The Association shall make arrangements to ensure that the proceeds of any financing are used only for the purposes for which the financing was provided, with due attention to considerations of economy, 
efficiency and competitive international trade and without regard to political or other noneconomic influences or considerations.

(h) Funds to be provided under any financing operation shall be made available to the recipient only to meet expenses in connection with the project as they are actually incurred.

Di dalam ketentuan hukum tersebut memberikan penjelasan bahwa IDA sebagai salah satu bagian dari Bank Dunia berupaya memberikan bantuan untuk pembangunan jangka panjang, khususnya kepada negaranegara berkembang yang menjadi anggota dari IDA. Tujuan dari pemberian bantuan tersebut untuk prioritas pembangunan negara penerima hibah, salah satunya adalah pada sektor pendidikan. Diharapkan dari bantuan yang diberikan oleh Bank Dunia tersebut, distribusi dan penggunaan dana hibah merata dengan koordinasi terkait pelaksanaan proyek tersebut pada pemerintah daerah dalam mendukung percepatan pencapaian target dari proyek yang didanai oleh Bank Dunia tersebut.

Norma hukum yang menjadi dasar bagi Bank Dunia tersebut telah membuka jalan bagi negara manapun di dunia berhak untuk mendapatkan bantuan kepada sektor pendidikan, karena fungsi Bank Dunia beserta struktur bank-bank yang ada dibawahnya adalah untuk kepentingan pembangunan bagi negara-negara berkembang dan dalam rangka membantu negara-negara tersebut secara finansial yang diturunkan di dalam proyekproyek implementatif dan spesifik terhadap sektor apakah diberikan bantuan dana tersebut.

Selain itu, tujuan dari diberikannya bantuan pendidikan tersebut adalah untuk kepentingan mempercepat pasar bebas yang kompetitif bagi negara penerima bantuan dengan melakukan serangkaian kegiatan pertimbangan ekonomi, tanpa memperhatikan pengaruh non-ekonomi dan politik lainnya untuk menjadi hambatan dalam tidak diberikannya bantuan dana tersebut.

\section{Ruang Lingkup Bantuan Bank Dunia}

Ruang lingkup bantuan yang diberikan oleh Bank Dunia untuk sektor pendidikan berdasarkan kerangka acuan kerja Education For All 2020 (EFA 2020) yang merupakan rencana jangka panjang pemenuhan hak atas pendidikan khususnya pada negara-negara berkembang, yaitu: ${ }^{21}$

(a) Reformasi sistem pendidikan, termasuk input dari pendidikan itu sendiri, hal-hal yang dibantu untuk mencapai target tersebut seperti pelatihan guru, ruangan sekolah, buku teks, standar kerja dari sistem pendidikan, aturan hukum, pertanggungjawaban, pembiayaan dan insentif bagi negara yang telah mencapai tujuan dari program, serta luaran yang akan terus menerus dimonitor;

(b) Membangun paradigma sistem pendidikan global yang dibangun dari reformasi pendidikan, hal tersebut ditunjukkan melalui kebijakan yang memperkuat sistem pendidikan dan mencapai tujuan dari pendidikan itu sendiri, Bank Dunia telah memiliki mekanisme evaluasi, penilaian dengan program yang disebut System Approach for Better Education Results (SABER), program ini mendorong untuk menganalisis kebijakan pembelajaran dan pembentukkan keterampilan bagi peserta didik bagi negara-negara penerima bantuan dana dari Bank Dunia.

SABER yang merupakan salah satu hasil dari rencana pencapaian Education for All dari Bank Dunia tersebut memberikan klasifikasi pada sektor apa saja bantuan terhadap pendidikan itu diberikan, yaitu: ${ }^{22}$

\footnotetext{
${ }^{21}$ Bank Dunia, Achieving the Learning..., Op.Cit. h. 23.

${ }^{22}$ Eric A. Hanushek dan Ludger Wößmann, Education Quality and Economy Growth, The World Bank Publisher, Washington D.C, 2007, h. 2-3.
} 
(a) Membantu negara-negara untuk mempercepat kinerja pencapaian Millenium Development Goals khususnya pada aspek pemenuhan pendidikan dasar secara menyeluruh, melalui hal tersebut Bank Dunia mengeluarkan 2,7 miliar US\$ yang disalurkan yang tunduk dengan aturan The IDA Agreement pada tahun 2011;

(b) Mengurangi ketidakadilan terhadap pemenuhan hak pendidikan, seperti akses dan keadilan pemenuhan pendidikan bagi anak-anak miskin di Pakistan, memperjuangkan hak peserta didik perempuan untuk bersekolah di Bangladesh, dan program keterampilan kerja bagi perempuan muda di Ethiopia dan Jordan;

(c) Memperbaiki kualitas dari pelayanan pendidikan, bantuan Bank Dunia dapat diketahui pada program bantuan peningkatan performa guru dan sekolah di Nigeria, bantuan sekolah bagi pencapaian rencana sekolah di Indonesia, ekspansi pelatihan bagi peserta didik di wilayah berkonflik dan dalam penguasaan negara lain di Rwanda, membantu penyusunan sistem penilaian kualitas peserta didik di negara-negara miskin dan berkembang seperti Ethiopia, Mozambique;

(d) Membuat ketentuan umum untuk mempercepat pencapaian tujuan pembelajaran, melalui kebijakan pendidikan yang berlaku di negara-negara penerima bantuan untuk termasuk kebijakan pengajaran, penilaian siswa, manajemen sekolah, dan tatalaksana pembangunan mutu pendidikan. Hal tersebut dilakukan melalui sistem yang modern dan akuntabel, agar baik Bank Dunia maupun pemerintah dari negaranegara penerima bantuan Bank Dunia memiliki tanggung jawab yang sama.

SABER kemudian menggandeng pihak-pihak terkait dalam mencapai target tersebut dengan kemitraan nasional yang terdiri dari peneliti, pembuat kebijakan, mitra eksternal dan pihak-pihak eksternal lainnya yang bertujuan untuk mendukung untuk merancang sistem pendidikan nasional yang berwawasan global, kemudian menilai kapasitas dan kebijakan negara terkait dengan tujuan khusus dibentuknya sistem pendidian, lalu berkaitan dengan contoh-contoh praktis dari negara pembanding, kemudian menganalisis kekuatan dan kelemahan sistem pendidikan nasional dengan standar pendidikan global termasuk praktik-praktik terbaik yang dilakukan oleh negara anggota, serta menghasilkan panduan reformasi untuk meningkatkan pemahaman untuk semua kerangka kerja reformasi pendidikan. ${ }^{23}$

Dari beberapa data mengenai bantuan Bank Dunia pada sektor pendidikan di beberapa negara termasuk Indonesia dapat diambil garis merah, bahwa pemenuhan hak pendidikan di negara-negara tersebut perlu mendapatkan intervensi dan dukungan dari Bank Dunia sendiri dalam rangka mencapai tujuan dari pelayanan pendidikan, serta memastikan dana bantuan yang diberikan telah dikerjakan dalam proyek-proyek pendidikan yang tepat sasaran. Berbagai macam cara, baik intervensi kebijakan, maupun harmonisasi aturan, sehingga negara penerima bantuan dana dari Bank Dunia diwajibkan mengikuti standar-standar yang ditentukan tersebut untuk diterapkan dalam kebijakan dan regulasi hukum nasional, sehingga tujuan besar dari bantuan pendidikan Bank Dunia dapat tercapai.

\section{Kesesuaian Standar Bantuan Bank Dunia dengan Pemenuhan Hak EKOSOB di Bidang Pendidikan di Indonesia}

Hak atas pendidikan merupakan amanah dari DUHAM 1948, pada Pasal 26 yang berbunyi:

Education shall be directed to the full development of the human personality and to the strengthening of respect for human rights and fundamental freedoms. It shall

23 Bank Dunia, Achieving the Learning...Op.Cit, h. 6163. 
promote understanding, tolerance and further the activities of the United Nations for the maintenance of peace

Di dalam pengertian Pasal 26 DUHAM 1948 memberikan penjelasan bahwa hak atas pendidikan dianggap menjadi bagian penting yang diatur di dalam mekanisme hukum dan HAM internasional, karena hak atas pendidikan merupakan satu diantara beberapa hak yang berupaya untuk memberikan derajat kehormatan yang ada didalam diri manusia secara inheren, pembangunan individu untuk memperbaiki nasib dan kesejahteraannya, memperkuat penghormatan terhadap HAM dan kebebasan individu, serta berupaya agar setiap individu dapat memahami arti pertemanan dan toleransi ditengah kehidupan sosial. ${ }^{24}$

Menurut Klaus Dieter Beiter, dimasukkannya hak tentang pendidikan tersebut pada regulasi hukum internasional adalah untuk memastikan seluruh individu menikmati akses terhadap pendidikan tanpa terkecuali, hal ini juga berkaitan dengan pemenuhan kebutuhan manusia, serta kepentingan dari negara untuk pembangunan SDM. Maka dari itu, hak atas pendidikan menjadi tanggung jawab negara yang merupakan amanah dari hukum internasional untuk memenuhi, apabila negara lalai atau bahkan tidak memenuhi hak atas pendidikan, maka bagi Beiter, negara sengaja melanggar hukum internasional yang notabene berlaku secara universal. ${ }^{25}$

Mike Cole berpendapat bahwa hak atas pendidikan mengandung makna bahwa setiap manusia berhak menikmati hak tanpa memandang ras, warna kulit, jenis kelamin, agama, derajat kecacatan, taraf kesejahteraan ekonomi, bahkan sampai pada pandangan politik, semua hal tersebut tidak bisa menjadi

24 UNICEF, A Human Right-Based Approach to Education for All: a Framework for the Realization of Children Right to Education and Right Within Education, United Nation Children's Fund, New York, h.7.

${ }^{25}$ Klaus Dieter Beiter, Op. Cit, h. 2. hambatan-hambatan bagi tidak terpenuhinya hak atas pendidikan bagi warga negara dan terdiskriminasi. ${ }^{26}$ Alasan-alasan tersebut harus dihilangkan agar menciptakan keadilan dalam pemenuhan hak atas pendidikan secara konstitusional.

Nilai penting yang dapat diambil, bahwa hak atas pendidikan merupakan hak yang sentral bagi suatu negara untuk melindungi, alasannya bahwa untuk menjadikan masyarakat menjadi individu yang bermartabat, sejahtera, dan berguna untuk pembangunan makro suatu negara lebih maju, maka seluruh masyarakat tanpa terkecuali dan tanpa diskriminasi berhak menikmati akses terhadap pendidikan. Hal tersebut dituangkan didalam konstitusi, perundang-undangan, kebijakan, serta praktik-praktik dalam kehidupan keseharian, sehingga untuk mewujudkan negara yang sejahtera, adil, dan makmur maka upaya prioritas untuk membenahinya adalah melalui pemenuhan hak atas pendidikan.

\section{Sasaran Pemenuhan Hak Atas Pendidikan}

Sasaran bagi hak atas pendidikan pengarusutaman terhadap murid, namun tidak menutup kemungkinan bahwa pemenuhan hak atas pendidikan juga berdampak signifikan bagi orang tua untuk memilih berbagai jenis pendidikan yang sesuai dengan keinginan dan kebutuhan anak-anaknya, serta kualitas pendidikan yang lebih baik, dan semua harapan tersebut dapat tercapai jika didukung dengan dimasukkannya hak atas pendidikan kedalam konstitusi hukum nasional, kebijakan, serta praktik-praktik perlindungan HAM dalam aspek pendidikan. ${ }^{27}$

Agar terwujud hak atas pendidikan tersebut, UNICEF yang merupakan salah satu kepanjangan tangan dari PBB yang menangani masalah pendidikan telah

\footnotetext{
${ }^{26}$ Mike Cole, Education, Equality and Human Right: Issues of Gender, Race, Sexuality, Disability and Social Class, Routledge, Oxfordshire, 2006, h.1-2.

27 Joel Spring, Op.Cit, h. 9-10.
} 
membuat kerangka acuan mengenai kewajiban dan tanggung jawab negara untuk memenuhi, menghormati, dan melindungi hak atas pendidikan khususnya bagi anak-anak, yaitu: ${ }^{28}$

(a) Memastikan dukungan politik dengan berbagai kebijakan serta kondisi perekonomian yang memadai dalam rangka memastikan bahwa seluruh peserta didik yang notabene anak-anak di negara tersebut dapat menikmati hak atas pendidikannya tanpa ada hambatan, maka dibutuhkan APBN yang surplus didukung dengan porsi dan distribusi yang merata dalam pendanaan akses pendidikan gratis;

(b) Komitmen politik yang kuat dari stake holder terkait untuk membuat kebijakan yang bertujuan kepada akses yang merata pada semua jenjang khususnya pendidikan dasar dan menengah, peningkatan kesejahteraan guru, serta infrastruktur pendidikan dan sarana prasarana yang memadai, selain itu diperkuat dengan prinsip-prinsip "good governance" yang dijalankan oleh stake holder, seperti: memberantas budaya mafia dan pungutan liar di dunia pendidikan, akuntabilitas dan transparansi anggaran, dan pemberdayaan kepada kekuatan sipil lainnya;

(c) Kebijakan makro-ekonomi dalam dunia pendidikan, semisal memberikan prosentase lebih pendanaan dalam APBN pada sektor pendidikan.

\section{Ketentuan Hukum Nasional Mengenai Hak Atas Pendidikan}

Didalam mekanisme hukum nasional, pengaturan mengenai hak pendidikan juga termasuk didalam UUD 1945 yang bertujuan untuk pemenuhan hak-hak konstitusional masyarakat Indonesia, norma mengenai hak pendidikan tertera pada Pasal 28C ayat (1) serta Pasal 31 ayat (1) - ayat (4) dan diturunkan pada Undang-Undang Nomor 39 tahun 1999, Undang-Undang Nomor 20 tahun

${ }^{28}$ UNICEF, Op. Cit, h.40-48.
2003. Dalam norma hukum nasional tersebut dapat dilihat, bahwa betapa besar komitmen Indonesia dalam pemenuhan hak atas pendidikan yang menjadi instrumen dalam mensejahterahkan dan kewajiban untuk mengenyam pendidikan dasar, serta penyelenggaraan sistem pendidikan nasional yang mencetak karakter seluruh masyarakat Indonesia.

Komitmen besar Indonesia dalam merubah kondisi pendidikan di Indonesia ada pada Pasal 31 ayat (4) UUD 1945, dimana negara mengalokasikan anggaran didalam anggaran pendapatan dan belanja negara (APBN) serta dari anggaran pendapatan dan belanja daerah (APBD) sekurang-kurangnya dua puluh persen $(20 \%)$, prosentase yang besar tersebut seyogianya dapat membuat pemenuhan hak atas pendidikan di Indonesia semakin lebih mudah. Hal yang perlu menjadi perhatian adalah berkenaan dengan alokasi dana tersebut agar dapat tepat sasaran.

Terkait dengan prosentase anggaran $20 \%$ didalam APBN berdasar Pasal 28C ayat (2) dan Pasal 31 ayat (4) UUD 1945 pernah menjadi dasar pengujian UU Nomor 16 Tahun 2008 tentang Perubahan Atas UndangUndang Nomor 45 Tahun 2007 tentang Anggaran Pendapatan dan Belanja Negara Tahun Anggaran 2008 terhadap UUD 1945 dihadapan Mahkamah Konstitusi (MK), hal tersebut dituangkan dalam Putusan Mahkamah Konstitusi Nomor 13/PUUVI/2008 tanggal 13 Agustus 2008, dengan Pemohon Prof. Dr. Muhammad Surya, dkk.

Dalam amar putusan, Majelis Hakim berpandangan bahwa:

(a) Menyatakan Permohonan para Pemohon dikabulkan;

(b) Menyatakan UU Nomor 16 Tahun 2008 tentang Perubahan Atas UU Nomor 45 Tahun 2007 tentang APBN Tahun 2008 (LNRI Nomor 63, tambahan LNRI Nomor 4848) bertentangan dengan UUD 1945 ;

(c) Menyatakan UU Nomor 16 Tahun 2008 tentang Perubahan Atas UU Nomor 45 Tahun 2007 tentang APBN Tahun 2008 
(LNRI Nomor 63, tambahan LNRI Nomor 4848) tetap berlaku sampai diundangkannya UU APBN Tahun Anggaran 2009.

Pertimbangan hukum dari Majelis Hakim MK dalam putusan PMK Nomor 13/PUU-VI/2008, adalah:

(a) Bahwa hak atas pendidikan sekuranhkurangnya $20 \%$ termasuk kewajiban imperatif (dwingend recht) dari negara yang dilindungi dalam UUD 1945, karena strategi pembanguan seharusnya menempatkan pendidikan sebagai human investment, maka pendidikan harus dipandang lebih penting dari bidangbidang lainnya;

(b) Bidang pendidikan seharusnya diprioritaskan tanpa menafikan bidangbidang lainnya, hal ini merupakan upaya terbaik, dan strategi fundamental untuk mendorong peningkatan kualitas sumber daya manusia dan membangun kemajuan kehidupan berbangsa dan bernegara di tengah kehidupan global yang membutuhkan kemampuan bersaing secara memadai;

(c) Kebijkan yang dianut dalam menyusun anggaran demikian harus diarahkan untuk meningkatkan kemampuan negara dalam melaksanakan kewajian konstitusionalnya untuk melaksanakan dan membiayai wajib belajar bagi pendidikan dasar, dengan melakukan realokasi dana dan fungsi-fungsi lain dalam APBN untuk fungsi pendidikan;

(d) Bahwa menurut ahli, terdapat beberapa prinsip pengemangan rumus pendanaan pendidikan, yaitu prinsip keadilan, prinsip kecukupan, prinsip keberlangsungan, prinsip efisiensi, dan prinsip akuntabilitas, yaitu:

- Prinsip keadilan mencakup: (i) kecukupan dana untuk menyelenggarakan kegiatan pokok pembelajaran, (ii) pemerataan antarsekolah, (iii) upaya penyeragaman fiskal untuk mengatasi perbedaan kemampuan ekonomi masyarakat, (iv) program pendidikan khusus, (v) program remedial, (vi) faktor diseconomies of scale karena letak geografis terpencil, (vii) beban pemerintah yang berat, (viii) perbedaan tingkat kemahalan antarwilayah;

- Prinsip kecukupan meliputi: (i) mata pelajaran/mata kuliah, (ii) tingkat kelas, (iii) jenjang pendidikan, (iv) jenis pendidikan (umum, kejuruan, keagamaan, vokasi, profesi);

- Prinsip keberlangsungan maksudnya adalah harus ada sumber dana tetap dan usaha memberdayakan satuan pendidikan;

- Prinsip efisiensi, maksudnya dengan dana yang sama dicapai hasil yang lebih tinggi;

- Prinsip akuntabilitas, maksudnya harus ada transparansi dan penggunaan biaya pendidikan sesuai dengan aturan dan mutu hasil;

- untuk satuan pendidikan, pendanaannya mengikuti rumus: biaya pokok penyelenggaraan pendidikan ditambah dengan indeks kemiskinan dan insentif peningkatan mutu. Sementara itu, biaya pokok penyelenggaraan pendidikan mencakup gaji dan tunjangan kesejahteraan guru, sarana (gedung, buku, komputer, perpustakaan, dan lain-lain), penunjang administrasi kegiatan belajar mengajar/tata usaha, serta kegiatan ekstrakurikuler, remedial, dan pengayaan;

(e) Bahwa cara penghitungan persentase anggaran pendidikan yang diterangkan Pemerintah yaitu perbandingan anggaran fungsi pendidikan terhadap total anggaran belanja negara (yang telah dikurangi dengan anggaran untuk beban subsidi energi dan pembayaran bunga utang) bukanlah cara penghitungan yang dianut oleh UU APBN-P 2008, sehingga tidak memiliki nilai hukum sebagai alat bukti untuk mempertimbangkan 
konstitusionalitas anggaran pendidikan dalam UU APBN-P 2008 dan oleh karenanya harus dikesampingkan;

(f) Bahwa telah ternyata anggaran pendidikan dalam UU APBN-P 2008 hanya sebesar $15,6 \%$, sehingga tidak memenuhi ketentuan konstitusional sekurang-kurangnya $20 \%$ dari anggaran pendapatan dan belanja negara. Dengan demikian, UU APBN-P 2008 bertentangan dengan UUD 1945, sehingga permohonan para Pemohon beralasan;

(g) Bahwa meskipun UU APBN-P 2008 bertentangan dengan UUD 1945, tetapi untuk menghindari risiko kekacauan dalam penyelenggaraan administrasi keuangan negara, UU APBN-P 2008 dinyatakan tetap berlaku sampai dengan diundangkannya Undang-Undang APBN Tahun Anggaran 2009.

Dalam amar putusan MK ini telah memberi justifikasi bahwa anggaran seminimminimnya yang dialokasikan oleh negara untuk sektor pendidikan tetap dalam prosentase $20 \%$ dari total APBN. hal ini bukan tanpa alasan, karena pendidikan merupakan sektor paling vital oleh negara untuk dipenuhi, sehingga jika prosentase anggaran $\leq 20 \%$ maka dapat dipastikan Undang-Undang APBN yang dialokasikan oleh Pemerintah setiap tahunnya akan inkonstitusional. Tentunya hal tersebut harus berbanding lurus dengan peningkatan mutu, aksesibelitas, dan daya jangkau atas penikmatan hak pendidikan itu sendiri.

Prosentase anggaran yang bersifat imperatif tersebut seyogianya dapat terserap dengan berbagai macam bantuan pendidikan serta alokasinya diprioritaskan untuk peningkatan mutu pendidikan, sarana dan prasarana pengajaran, kesejahteraan tenaga pengajar, serta yang terakhir infrastruktur pendidikan.

\section{Analisis Bantuan Bank Dunia Sektor Pendidikan di Indonesia}

Sebagai salah satu negara berkembang yang sering mendapatkan pinjaman maupun bantuan dari Bank Dunia, ada beberapa perjanjian bantuan (grant agreement) maupun perjanjian hutang (soft loan) yang dilakukan oleh pemerintah Indonesia dengan Bank Dunia melalui IBRD yang salah satunya dalam sektor pendidikan, yaitu:

\section{a. PNPM Support Facility Trust Fund (PSF) Grant Agreement}

Perjanjian bantuan dana (grant agreement) yang pernah dilakukan oleh Indonesia adalah dalam PNPM Support Facility Trust Fund (PSF) Grant Agreement yang dituangkan dalam grant no. TF099616ID. Perjanjian ini merupakan bantuan kepada multi-projek hibah dengan fokus utamanya adalah pembangunan di daerah pedesaan, dimana perjanjian hibah tersebut disahkan pada 6 Juni 2011, dimana donor dana tersebut dituangkan oleh Bank Dunia melalui program Support Facility for the National Program for Community Empowerment Multi Donor Trust Fund (TF070967 and TF071562) ("PSF").

Berdasarkan Pasal 3.02, bantuan ini diberikan secara berkala untuk disalurkan, bantuan tersebut disalurkan sebesar US\$ 32.700.000. berdasarkan Pasal 4.02 dari grant agreement tersebut, bantuan disalurkan kepada Kementerian Keuangan. Pada rencana 1 point $1 . b$ dari proyek yang mendapatkan bantuan tersebut, bantuan untuk meningkatkan mutu pendidikan di pedesaan disebut "kecamatan grant", dimana bantuan terhadap pendidikan dasar dan menengah diperuntukkan untuk menurunkan angka kemiskinan, pengangguran, dan upaya untuk pembangunan desa, bantuan ini dituangkan dalam program-program seperti: pelatihan guru, bantuan pembangunan infrastruktur sekolah, dan peningkatan pembelajaran berbasis Desa.

Dalam konteks PNPM Support Facility Trust Fund (PSF) Grant Agreement, bantuan tersebut sejalan dengan karakteristik Indonesia yang terdiri dari ribuan pulau 
dengan lingkup pemerintahan terkecil adalah desa, dimana disetiap desa di Indonesia memiliki karakteristiknya sendiri, dengan bantuan tersebut diharapkan agar dapat menciptakan pembangunan secara buttom up yang berangkat dari Desa.

\section{b. Indonesia-BOS Knowledge Improvement For Transparency And Accountability}

Program Bantuan Operasiona Sekolah

(BOS) yang ditandatangani pada 30 Desember 2013 merupakan salah satu perjanjian pinjaman lunak (soft loan) antara Pemerintah Indonesia dengan IBRD. Bantuan tersebut dituangkan dalam sektor pendidikan dasar sebesar $70 \%$ dan pendidikan menengah sebanyak $30 \%$, bantuan ini termasuk bantuan gelombang 2 dari BOS yang telah ditandatangani sebelumnya, dengan meningkatkan pinjaman sebesar US\$ 2.000.000 pada tahun 2005 .

Perjanjian ini dituangkan dalam Indonesia - Bos Knowledge Improvement For Transparency And Accountability dengan loan agreement no. P107661. Pinjaman tersebut sebesar US\$ 10.190 .000 yang dituangkan dalam beberapa program seperti: bantuan dana operasional sekolah, beasiswa dan jaminan pendidikan bagi anak-anak usia sekolah 7-15 tahun, bantuan infrastruktur sekolah, pelatihan untuk tim BOS, dan studi komprehensif sekolah berbasis manajemen.

Bantuan dana ini bertujuan untuk meningkatkan akses dan kualitas pendidikan Indonesia dengan memperkuat partisipasi masyarakat, memperbaiki transparansi dan akuntabilitas pengelolaan anggaran pendidikan, dan pemanfaatan untuk biaya operasional sekolah, hal ini dalam rangka untuk mewujudkan perlindungan pendidikan bagi masyarakat Indonesia yang dituangkan dalam Konstitusi UUD 1945.

Secara umum, hasil yang didapatkan dari proyek pinjaman dana ini adalah peningkatan prosentase penerima hibah dari 47\% pada tahun 2008 menjadi $80 \%$ pada tahun 2012. ${ }^{29}$ Kemudian pemerataan anggaran tersebut dapat dinikmati semua Provinsi dan Kabupaten/Kota se-Indonesia sebanyak 93\%. Evaluasi dari proyek pinjaman lunak ini adalah bagaimana intervensi dari Bank Dunia terhadap implementasi dari program-program yang dicanangkan dalam BOS ini. Hal ini cukup beralasan, karena Bank Dunia menginginkan agar pinjaman yang diberikan dapat tepat sasaran serta dapat kembali dengan jangka waktu sesuai klausul, hal yang menjadi kejanggalan adalah terkait dengan kebebasan dari negara peminjam untuk melakukan improvisasi pengelolaan pinjaman tersebut dan mengaturnya sesuai dengan kebijakannya sendiri.

\section{c. Kiat Guru: Kinerja Dan Akuntabilitas Guru - Improving Teacher Performance And Accountability}

"Kiat Guru: Kinerja Dan Akuntabilitas Guru - Improving Teacher Performance And Accountability", merupakan perjanjian pinjaman lunak antara Indonesia dengan Bank Dunia yang menyentuh sektor peningkatan kualitas guru yang menjadi satu instrumen dari pengembangan mutu pendidikan di Indonesia. Proyek yang ditandatangani pada 31 Maret 2016 tersebut berkisar 208 Triliun Rupiah/ US\$ 15.400.000. Dana sebesar itu dialokasikan untuk pembayaran guru di Indonesia, dengan Loan Agreement No. C56822.

Program ini bertujuan meningkatkan kesejahteraan guru secara signifikan melalui program sertifikasi, insentif guru, dan segala program lain untuk menciptakan reformasi manajemen guru di Indonesia. Salah satunya mendukung dibentuknya Undang-Undang Nomor 5 Tahun 2014 tentang Aparatur Sipil negara untuk kinerja guru Pegawai Negeri Sipil (PNS) berbasis prestasi, dimana sistem

\footnotetext{
${ }^{29}$ Bank Dunia, Independent Evaluation Group Review; Indonesia-BOS Knowledge Improvement For Transparency And Accountability (Report No: ICRR14275), The World Bank Publisher, Washington D.C., 2013, h.3.
} 
birokrasi guru mendorong evaluasi berbasis kinerja dan penggunaan insentif sebagai basis kinerja. Kemudian juga mendukung dibentuknya Undang-Undang Nomor 6 Tahun 2014 tentang Desa, dimana menyediakan kerangka kerja untuk pemberdayaan masyarakat dengan alokasi anggaran bagi guru yang didesiminasi pada setiap desa di Indonesia per-tahun, hal ini bertujuan untuk meningkatkan kualitas guru yang ada di pedesaan dengan prinsip transparansi dan keterbukaan. ${ }^{30}$ Pemberian dana yang diperuntukkan untuk guru dengan total pinjaman sebesar tersebut seyogianya dapat dikontrol dan diawasi oleh semua pihak, karena pembiayaan guru harus berbanding lurus dengan peningkatan kualitas dan perbaikan mutu pendidikan di Indonesia, dimana dari pinjaman tersebut dapat mencetak guru-guru yang profesional, inovatif, dan berkompeten, tanpa mengkhawatirkan aspek kesejahteraan lagi.

Dari beberapa data mengenai bantuan Bank Dunia pada sektor pendidikan di beberapa negara termasuk Indonesia dapat diambil garis merah, bahwa pemenuhan hak pendidikan di negara-negara tersebut perlu mendapatkan intervensi dan dukungan dari Bank Dunia sendiri dalam rangka mencapai tujuan dari pelayanan pendidikan, serta memastikan dana bantuan yang diberikan telah dikerjakan dalam proyek-proyek pendidikan yang tepat sasaran. Berbagai macam cara, baik intervensi kebijakan, maupun harmonisasi aturan, sehingga negara penerima bantuan dana dari Bank Dunia diwajibkan mengikuti standar-standar yang ditentukan tersebut untuk diterapkan dalam kebijakan dan regulasi hukum nasional, sehingga tujuan besar dari bantuan pendidikan Bank Dunia dapat tercapai.

\footnotetext{
${ }^{30}$ Bank Dunia, Project Information Document (PID) Identification/Concept Stage; KIAT GURU: Kinerja dan Akuntabilitas Guru "Improving Teacher Performance and Accountability"(Report No:PIDC56822), The World Bank Publisher, Washington D.C., 2016, h.2-3.
}

\section{Batas Pemenuhan dan Pelanggaran Oleh Negara Terhadap Hak Atas Pendidikan}

Berkaitan dengan batasan pemenuhan hak atas pendidikan, apabila menggunakan pendekatan yang digunakan oleh Katarina Tomasevski yang merupakan pelapor khusus Komisi EKOSOB PBB, mempunyai konsep untuk mengukur pemenuhan hak-hak EKOSOB, yaitu 4-A dimana hal tersebut juga dituangkan dalam Komentar Umum 13 Kovenan EKOSOB ada beberapa poin dimana negara pihak wajib melaksanakannya, yaitu: ketersediaan (availability), keterjangkauan (accessibility), keterterimaan (acceptability), kesesuaian (adaptability). Ketersediaan (availability), berkaitan dengan pelaksanaan fungsi pemenuhan hak-hak EKOSOB beserta berbagai macam sumber daya (resources) yang ada juga berkenaan dengan adanya program yang mendukung hal tersebut, namun demikian bergantung kepada kapasitas taraf pembangunan negara masing-masing. ${ }^{31}$

Kemudian berkaitan dengan keterjangkauan (accessibility), dimana pasca tersedianya berbagai macam sumber daya yang ada dalam mendukung hak-hak tersebut kemudian yang dapat dilihat adalah keterjangkauan dalam rangka pemenuhan hak-hak terkait, misalnya: semua fasilitas dalam pemenuhan hak-hak EKOSOB peruntukannya tidak diskriminatif, lalu bagaimana keterjangkauan fisik, keterjangkauan ekonomi (affordability), serta keterjangkauan informasi tidak menimbulkan kesenjangan dalam penikmatan hak tersebut.

Lalu mengenai keterterimaan (acceptability), apakah kemudian berbagai macam sarana dan sumber daya dalam rangka pemenuhan hak-hak EKOSOB tersebut sesuai dengan kehendak dan tidak bertentangan dengan nilai adat budaya, agama, kesopanan, dan tata krama dalam masyarakat, hal tersebut juga menjadii varian penting dalam pemenuhan hak-hak EKOSOB. Terakhir,

\footnotetext{
${ }^{31}$ Mimin Rukmini, et.al, Pengantar Memahami Hak EKOSOB, Pusat Telaah dan Informasi Regional (PATTIRO), Jakarta, 2006, h.29-34, juga bisa dilihat di Komnas HAM, Ibid.
} 
adaptability (kebersesuaian) yang berkaitan dengan kualitas dan tersedianya berbagai macam sumber daya ini secara layak dan bermutu dapat dirasakan manfaatnya oleh masyarakat.

\begin{tabular}{|c|c|c|}
\hline Aspek & $\begin{array}{c}\text { Masalah } \\
\text { Pokok }\end{array}$ & $\begin{array}{c}\text { Contoh yang } \\
\text { Baik }\end{array}$ \\
\hline $\begin{array}{l}\text { Ketersedia } \\
\text { an }\end{array}$ & 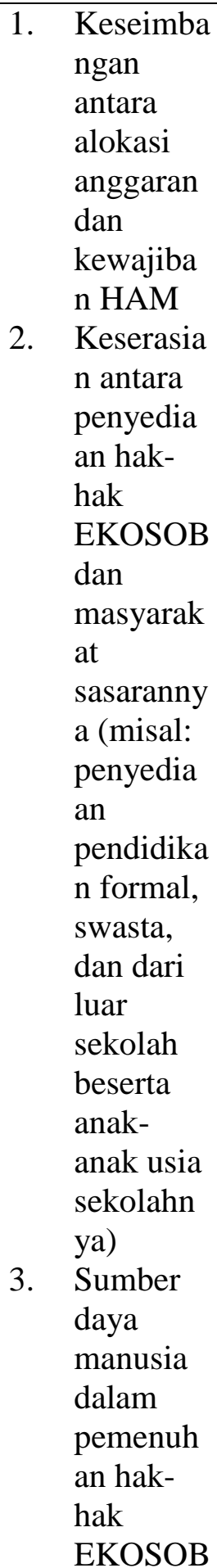 & $\begin{array}{l}\text { 1. Alokasi } \\
\text { anggaran } \\
\text { didasarkaa } \\
\text { n pada } \\
\text { perkiraan } \\
\text { biaya } \\
\text { pendidika } \\
\text { n } \\
\text { berkualita } \\
\text { s untuk } \\
\text { semua } \\
\text { kewajiban } \\
\text { ditambah } \\
\text { dengan } \\
\text { perbaikan } \\
\text { HAM dan } \\
\text { minimalisi } \\
\text { r } \\
\text { pelanggar } \\
\text { an. } \\
\text { 2. Mengiden } \\
\text { tifikasi } \\
\text { hambatan } \\
\text { dan } \\
\text { ukuran } \\
\text { untuk } \\
\text { mengatasi } \\
\text { nya. } \\
\text { 3. Pengamat } \\
\text { an HAM } \\
\text { dan } \\
\text { standar } \\
\text { hukum } \\
\text { tenaga } \\
\text { kerja } \\
\text { untuk } \\
\text { guru (SOP } \\
\text { model } \\
\text { guru ideal } \\
\text { dalam }\end{array}$ \\
\hline
\end{tabular}

\begin{tabular}{|c|c|c|c|}
\hline & & $\begin{array}{l}\text { (misal: } \\
\text { profesi } \\
\text { pengajara } \\
\mathrm{n} \\
\text { bagaiman } \\
\text { a dapat } \\
\text { terstandar } \\
\text { t) }\end{array}$ & $\begin{array}{l}\text { pembelaja } \\
\text { ran) }\end{array}$ \\
\hline $\begin{array}{l}\text { Keterjang } \\
\text { kauan }\end{array}$ & 4. & $\begin{array}{l}\text { Pemantau } \\
\text { an anak- } \\
\text { anak di } \\
\text { luar } \\
\text { sekolah } \\
\text { secara } \\
\text { terus } \\
\text { menerus } \\
\text { dan } \\
\text { mengiden } \\
\text { tifikasi } \\
\text { mengapa } \\
\text { tidak } \\
\text { dapat } \\
\text { menikmat } \\
\text { i hak atas } \\
\text { pendidika } \\
\text { n. } \\
\text { Mengide } \\
\text { ntifikasi } \\
\text { semua } \\
\text { hambatan } \\
\text { menamat } \\
\text { kan } \\
\text { pendidika } \\
\text { n wajib } \\
\text { bagi } \\
\text { anak- } \\
\text { anak }\end{array}$ & $\begin{array}{l}\text { 4. Ukuran- } \\
\text { ukuran } \\
\text { yang } \\
\text { menjamin } \\
\text { anak-anak } \\
\text { di luar } \\
\text { jangkauan } \\
\text { dapat } \\
\text { masuk } \\
\text { sekolah, } \\
\text { atau } \\
\text { menyedia } \\
\text { kan } \\
\text { pendidika } \\
\text { n di } \\
\text { tempat } \\
\text { mereka } \\
\text { berada. } \\
\text { 5. Stategi } \\
\text { menyeluru } \\
\text { h untuk } \\
\text { penghilan } \\
\text { gan semua } \\
\text { hambatan } \\
\text { (secara } \\
\text { hukum, } \\
\text { administra } \\
\text { si, } \\
\text { keuangan, } \\
\text { dsb) }\end{array}$ \\
\hline $\begin{array}{l}\text { Kebersesu } \\
\text { aian }\end{array}$ & 6. & $\begin{array}{l}\text { Menentu } \\
\text { kan } \\
\text { spesifikas } \\
\text { i dari } \\
\text { standar } \\
\text { kualitas } \\
\text { Pengajara } \\
\text { n } \\
\text { berdasark } \\
\text { an HAM }\end{array}$ & $\begin{array}{l}\text { 6. Pengawas } \\
\text { an semua } \\
\text { lembaga } \\
\text { pendidika } \\
\text { n untuk } \\
\text { menjamin } \\
\text { penyesuai } \\
\text { an } \\
\text { dengan } \\
\text { standar }\end{array}$ \\
\hline
\end{tabular}




\begin{tabular}{|c|c|c|}
\hline & $\begin{array}{ll}\text { 8. } & \text { Penghilan } \\
\text { gan } \\
\text { semua } \\
\text { hambatan } \\
\text { dalam } \\
\text { belajar }\end{array}$ & 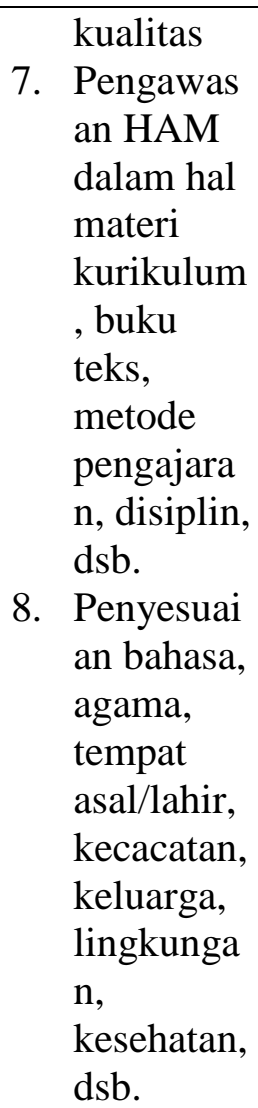 \\
\hline $\begin{array}{l}\text { Keberteri } \\
\text { maan }\end{array}$ & $\begin{array}{ll}\text { 9. } & \text { Penyesua } \\
\text { ian hak- } \\
\text { hak } \\
\text { semua } \\
\text { umur } \\
\text { 10. } \\
\text { Membent } \\
\text { uk } \\
\text { pendidika } \\
\text { n untuk } \\
\text { menegak } \\
\text { kan } \\
\text { semua } \\
\text { standar- } \\
\text { standar } \\
\text { HAM }\end{array}$ & 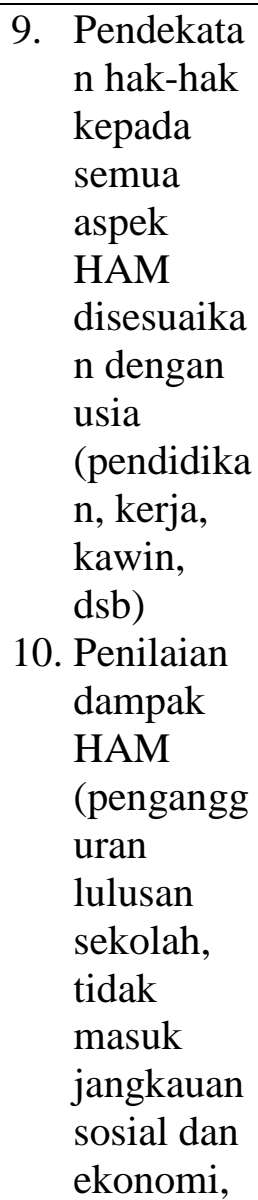 \\
\hline
\end{tabular}

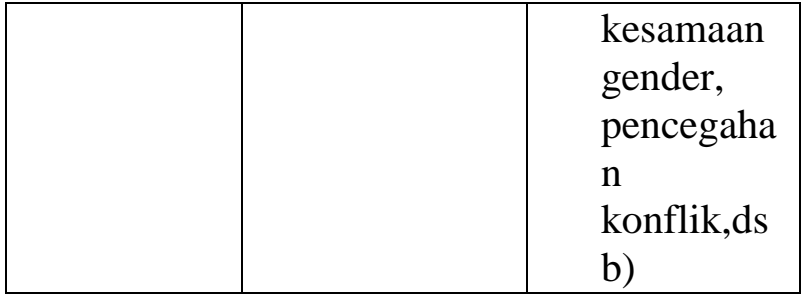

Tabel 3: contoh-contoh terbaik dalam memantau pemenuhan hak atas pendidikan berbasis HAM $^{32}$

Dalam guidence dan ketentuan perlindungan hak atas pendidikan dalam regulasi hukum nasional yang telah dijelaskan dimuka, terdapat multidimensi sudut pandang dalam melihat komitmen suatu negara dalam pemenuhan hak-hak EKOSOB dan pada tahap apakah negara dapat dikategorikan melanggar hak-hak EKOSOB. selain itu, pemenuhan hak atas pendidikan tersebut haruslah fleksibel sehingga dapat menyesuaikan diri dengan kebutuhan para peserta didik dan masyarakat dalam negara tersebut, dan kebijakan yang dibuat seyogianya mempertimbangkan kepentingan dan kebutuhan para peserta didik.

\section{Kesesuaian Bantuan Dana Bank Dunia Dalam Sektor Pendidikan Sebagai Hak EKOSOB}

Menguji kesesuaian bantuan dana Bank Dunia dalam sektor pendidikan sebagai upaya dalam mendukung pemenuhan hak-hak EKOSOB maka perlu menganalisis keterkaitan (relation) antara prinsip-prinsip dalam SABER $^{33}$ dan pendekatan pemenuhan hak-hak EKOSOB 4-A yang disampaikan oleh Katarina Tomasesvski dan dituangkan dalam Komentar Umum 13 Kovenan EKOSOB, yaitu: ketersediaan (availability), keterjangkauan (accessibility), keterterimaan (acceptability), kebersesuaian (adaptability). Ketersediaan (Availability).

\footnotetext{
${ }^{32}$ Mimin Rukmini, et.al, Ibid.

${ }^{33}$ Bank Dunia, SABER Overview; The What, Why, and How of the Systems Approach for Better Education Results, The World Bank Press,New York, 2013, h. 1013.
} 


\begin{tabular}{|c|c|c|}
\hline Metode 4-A & $\begin{array}{l}\text { Prinsip- } \\
\text { Prinsip } \\
\text { SABER }\end{array}$ & $\begin{array}{l}\text { Mengukur } \\
\text { Hubungan } \\
\text { (Measureme } \\
\text { nt Relation) }\end{array}$ \\
\hline Ketersediaan & $\begin{array}{l}\text { Seberapa } \\
\text { efisien } \\
\text { sumber daya } \\
\text { yang } \\
\text { digunakan } \\
\text { untuk } \\
\text { meningkatka } \\
\mathrm{n} \\
\text { pembelajara } \\
\text { n yang } \\
\text { alokasinya } \\
\text { tergantung } \\
\text { pada } \\
\text { kebijakan } \\
\text { pendidikan } \\
\text { dari } \\
\text { pelaksana } \\
\text { program, } \\
\text { yaitu negara } \\
\text { penerima } \\
\text { bantuan } \\
\text { dana Bank } \\
\text { Dunia }\end{array}$ & $\begin{array}{l}\text { Dengan } \\
\text { efisiensi } \\
\text { tersebut, } \\
\text { diharapkan } \\
\text { agar } \\
\text { terciptanya } \\
\text { prinsip } \\
\text { transparansi } \\
\text { dan } \\
\text { akuntabilitas } \\
\text { dalam } \\
\text { mengelola } \\
\text { anggaran } \\
\text { untuk } \\
\text { pemenuhan } \\
\text { hak atas } \\
\text { pendidikan } \\
\text { seluas- } \\
\text { luasnya }\end{array}$ \\
\hline $\begin{array}{l}\text { Keterjangka } \\
\text { uan }\end{array}$ & $\begin{array}{l}\text { Domain } \\
\text { yang } \\
\text { menjadi } \\
\text { penilaian } \\
\text { SABER } \\
\text { yang akan } \\
\text { ditingkatkan } \\
\text { dalam mutu } \\
\text { pendidikan } \\
\text { nasional }\end{array}$ & $\begin{array}{l}\text { Pembagian } \\
\text { skala } \\
\text { prioritas } \\
\text { 1. Prioritas } \\
\text { utama: } \\
\text { pembang } \\
\text { unan } \\
\text { karakter } \\
\text { peserta } \\
\text { didik } \rightarrow \\
\text { sumber } \\
\text { daya yang } \\
\text { dinilai: } \\
\text { kualitas } \\
\text { peserta } \\
\text { didik } \rightarrow \\
\text { dukungan } \\
\text { pemerinta } \\
\text { h: } \\
\text { Pendanaa } \\
\text { n dan }\end{array}$ \\
\hline
\end{tabular}

\begin{tabular}{|c|c|c|}
\hline & & $\begin{array}{l}\text { beasiswa } \\
\text { sekolah } \\
\text { 2. Membang } \\
\text { un } \\
\text { kerangka } \\
\text { kerja } \\
\text { sekolah : } \\
\text { Guru dan } \\
\text { TI } \\
\text { Pembelaj } \\
\text { aran } \rightarrow \\
\text { dukungan } \\
\text { pemerinta } \\
\text { h: } \\
\text { otonomi } \\
\text { sekolah } \\
\text { dan } \\
\text { akuntabili } \\
\text { tas, } \\
\text { membuat } \\
\text { sekolah } \\
\text { berbasis } \\
\text { IT } \\
\text { 3. Kebutuha } \\
\text { n tersier } \\
\text { pendidika } \\
\text { n: unit } \\
\text { kesehatan } \\
\text { sekolah } \\
\text { dan } \\
\text { pemberia } \\
\text { n } \\
\text { makanan } \\
\text { di sekolah } \\
\rightarrow \\
\text { dukungan } \\
\text { pemerinta } \\
\text { h: } \\
\text { bekerjasa } \\
\text { ma } \\
\text { dengan } \\
\text { sektor } \\
\text { privat } \\
\end{array}$ \\
\hline $\begin{array}{l}\text { Kebersesuaia } \\
\text { n }\end{array}$ & $\begin{array}{l}\text { SABER } \\
\text { memungkin } \\
\text { kan } \\
\text { Pemangku } \\
\text { Kebijakan }\end{array}$ & $\begin{array}{l}\text { SABER } \\
\text { menilai hasil } \\
\text { tersebut } \\
\text { setelah } \\
\text { negara }\end{array}$ \\
\hline
\end{tabular}

Bantuan Dana Bank Dunia dalam Perspektif Pemenuhan Hak-hak EKOSOB; 


\begin{tabular}{|c|c|c|}
\hline & $\begin{array}{l}\text { untuk } \\
\text { melihat } \\
\text { antara target } \\
\text { pendidikan } \\
\text { dan hasil } \\
\text { dari proses } \\
\text { pendidikan } \\
\text { itu sendiri } \\
\text { 1. Jumlah } \\
\text { anggaran } \\
\text { yang } \\
\text { dihabiska } \\
\text { n untuk } \\
\text { membang } \\
\text { un } \\
\text { sekolah } \\
\text { 2. Jumlah } \\
\text { anggaran } \\
\text { untuk } \\
\text { melihat } \\
\text { jumlah } \\
\text { guru yang } \\
\text { tersedia } \\
\text { 3. Kompete } \\
\text { nsi } \\
\text { lulusan }\end{array}$ & $\begin{array}{l}\text { penerima } \\
\text { bantuan dari } \\
\text { Bank Dunia } \\
\text { untuk } \\
\text { menciptakan } \\
\text { suatu } \\
\text { standar } \\
\text { kualitas } \\
\text { global } \\
\text { pendidikan } \\
\text { terhadap } \\
\text { negara } \\
\text { penerima } \\
\text { bantuan }\end{array}$ \\
\hline $\begin{array}{l}\text { Keberterima } \\
\text { an }\end{array}$ & $\begin{array}{l}\text { Mencapai } \\
\text { segala } \\
\text { macam } \\
\text { target dari } \\
\text { tujuan } \\
\text { pendidikan } \\
\text { global } \\
\text { dengan jalan } \\
\text { formal dan } \\
\text { kebijakan } \rightarrow \\
\text { mengacu } \\
\text { pada kualitas } \\
\text { dan hasil } \\
\text { pasca } \\
\text { adanya } \\
\text { penerapan } \\
\text { standar } \\
\text { pendidikan } \\
\text { global }\end{array}$ & $\begin{array}{l}\text { Terhambat } \\
\text { atas kondisi } \\
\text { berbagai } \\
\text { karakteristik } \\
\text { yang } \\
\text { berbeda } \\
\text { antar- } \\
\text { negara, } \\
\text { bahkan } \\
\text { situasi dan } \\
\text { kondisi } \\
\text { masing- } \\
\text { masing } \\
\text { daerah di } \\
\text { internal } \\
\text { suatu negara } \\
\text { untuk } \\
\text { menerima } \\
\text { standar } \\
\text { tersebut }\end{array}$ \\
\hline
\end{tabular}

Tabel 5:Measurement relation antara SABER dengan metode 4-a pemenuhan hak EKOSOB $^{34}$

Didalam tabel yang mencoba melihat mengukur keterkaitan (measurement relation) antara standar 4-a untuk mengetahui apakah suatu negara memenuhi hak-hak EKOSOB dari masyarakatnya, khususnya hak atas pendidikan dengan standarisasi SABER yang merupakan turunan dari Education For All 2020 milik Bank Dunia ada kesesuaian yang hampir secara keseluruhan identik mulai dari ketersediaan, kebersesuaian, dan keterjangkauan, artinya bahwa misi bantuan pendidikan Bank Dunia pada sektor pendidikan telah selaras dengan tujuan untuk pemenuhan hak-hak EKOSOB, khususnya hak atas pendidikan.

Persoalan besarnya berkaitan dengan keberterimaan, karena standar pendidikan global yang dicanangkan oleh Bank Dunia adakalanya tidak sesuai dengan ciri khas masyarakat yang menerima langsung pelayanan pendidikan tersebut, karena jalan yang ditempuh oleh SABER hanya pada formalitas kebijakan yang dibuat oleh Pemerintah, namun harus memperhatikan karakteristik masing-masing negara dan kondisi internal dari negara penerima bantuan dana.

Pandangan bahwa bantuan dana yang diberikan oleh Bank Dunia digunakan untuk alasan menerapkan standar pendidikan global secara mutlak, karena seharusnya pemenuhan hak atas pendidikan harus memperhatikan local wisdom dari masing-masing negara serta kondisi internal dari negara penerima bantuan, sehingga pemenuhan hak atas pendidikan betul-betul dapat maksimal dan digunakan untuk kepentingan pembangunan pendidikan suatu negara.

\section{E. KESIMPULAN}

Beberapa data mengenai bantuan Bank Dunia pada sektor pendidikan di beberapa negara termasuk Indonesia, bahwa

\footnotetext{
${ }^{34}$ Ibid, h. 13.
} 
pemenuhan hak pendidikan di negara-negara berkembang perlu mendapatkan intervensi dan dukungan dari Bank Dunia sendiri dalam rangka mencapai tujuan dari pelayanan pendidikan, serta memastikan dana bantuan yang diberikan telah dikerjakan dalam proyek-proyek pendidikan yang tepat sasaran.

Berbagai macam cara, baik intervensi kebijakan, maupun harmonisasi aturan, sehingga negara penerima bantuan dana dari Bank Dunia diwajibkan mengikuti standarstandar yang ditentukan tersebut untuk diterapkan dalam kebijakan dan regulasi hukum nasional, sehingga tujuan besar dari bantuan pendidikan Bank Dunia menciptakan competitiveness peserta didik di era persaingan global bagi negara-negara penerima bantuan dapat terpenuhi.

Kesesuaian negara memenuhi hak-hak EKOSOB dari masyarakatnya khususnya hak atas pendidikan dengan standarisasi SABER yang merupakan turunan dari Education for All 2020 milik Bank Dunia ada kesesuaian yang hampir secara keseluruhan identik mulai dari ketersediaan, kesesuaian, dan keterjangkauan, artinya bahwa misi bantuan pendidikan Bank Dunia pada sektor pendidikan telah selaras dengan tujuan untuk pemenuhan hak-hak EKOSOB, khususnya hak atas pendidikan.

Persoalan besarnya berkaitan dengan acceptability, karena standar pendidikan global yang dicanangkan oleh Bank Dunia adakalanya tidak sesuai dengan ciri khas masyarakat yang menerima langsung pelayanan pendidikan tersebut, karena jalan yang ditempuh oleh SABER hanya pada formalitas kebijakan yang dibuat oleh Pemerintah, namun harus memperhatikan karakteristik masing-masing negara dan kondisi internal dari negara penerima bantuan dana, sehingga tidak timbul pandangan bahwa bantuan dana yang diberikan oleh Bank Dunia digunakan untuk alasan menerapkan standar pendidikan global secara mutlak.

\section{Saran}

Diperlukan Kesepakatan yang win-win solution antara negara penerima bantuan dana pendidikan dengan Bank Dunia agar tidak ada yang dirugikan dalam berbagai macam perjanjian bantuan dana Bank Dunia dalam sektor pendidikan.

Pengetahuan mengenai perlindungan, penghormatan, dan pemenuhan hak atas pendidikan dan mekanisme hukum bagi pelanggaran hak-hak EKOSOB, maka diharapkan adanya partisipasi aktif dari masyarakat Indonesia untuk mengawal pemenuhan hak atas pendidikan yang dilindungi dalam konstitusi maupun hukum internasional agar tidak dilanggar sewenangwenang oleh negara.

\section{DAFTAR PUSTAKA}

\section{Buku}

Aldhof, Huala, "Hukum Ekonomi Internasional: Suatu Pengantar”, Keni Media, Bandung, 2010.

Asplund, Knut D., et.al, "Hukum Hak Asasi Manusia”, PUSHAM UII, Jogjakarta, 2008.

Bank Dunia, "Achieving the Learning For $A l$ " $l$, The World Bank Press, New York, 2013.

-------------, "Priorities And Strategies for Education; A World Bank Review”, The World Bank Publisher, Washington D.C., 1995

----------,'SABER Overview; The What, Why, and How of the Systems Approach for Better Education Results", The World Bank Press,New York, 2013. , Independent Evaluation Group

Review; Indonesia-BOS Knowledge Improvement For Transparency And Accountability (Report No: ICRR14275), The World Bank Publisher, Washington D.C., 2013.

----------, Project Information Document (PID) Identification/Concept Stage; KIAT GURU: Kinerja dan Akuntabilitas Guru "Improving Teacher Performance and Accountability"(Report No: 
PIDC56822), The World Bank Publisher, Washington D.C., 2016

Bernstein Tarrow, Norma, et.al, "Human Rights and Education", Pergamon Press, Oxfordshire, 1987

Cole, Mike, "Education, Equality and Human Right: Issues of Gender, Race, Sexuality, Disability and Social Class", Routledge, Oxfordshire, 2006.

Couret Blanco, Manuel, "Economic Versus Human Rights”, Routledge, New York, 2009.

Dieter Beiter, Klaus, "The Protection of the Right to Education by International Law", Martinus Nijhoff Publisher, Leiden, 2006.

Independent Evaluation Group, "From Schooling Access to Learning Outcomes; an Unfinished Agenda", The World Bank Press, Washington DC, 2006

J. Kless, Steven, et.al, "Economy, Aid, and Education", Sense Publisher, Rotterdam, 2006.

Khaliq, Urfan dan Robin Churchill, et.al, "UN Human Right Treaty Bodies; Law and Legitimacy", Cambridge Publisher, New York, 2012.

Langford, Malcolm, "Social Right Jurisprudence; Emerging Trends in International and Comparative Law", Cambridge University Press, New York, 2009.

N Shaw, Malcolm, "International Law (6th edition)", Cambridge University Press, New York, 2008.

Peter Mahmud Marzuki, Penelitian hukum, Kencana Prenada Group, Jakarta, 2005.

PBB, "Economic, Social and Cultural Rights; Handbook for National Human Rights Institutions (Professional Training Series No.12)", UN Publishing, New York, 2005.

-----, "Human Right Indicators; A Guide to Measurement and Implementation", UNHR Office of the High Commition, New York, 2012
Parkinson, Nancy, "Education Aid and National Development; an International Comparison of the Past and Recommendations for the Future", Macmillan Press, New York, 1976.

Rukmini, Mimin, et.al, "Pengantar Memahami Hak EKOSOB", Pusat Telaah dan Informasi Regional (PATTIRO), Jakarta, 2006.

Sieghart, Phillip, "The International Law of Human Right", Clarendon Press, Oxfordshire, 1983.

Spring, Joel, "The Universal Right to Education; Justification, Definiton, and Guidelines", Lawrence Erlbaum Associates, inc., London

Ssenyonjo, Manissuli, et.al., "International human Right Law; Six Decades after the UDHR and Beyond", Ashgate Publishing, Burlington, 2010.

Steven J. Kless, et.al., "The World Bank and Education; Critiques and Alternatives", Sense Publisher, Roterdam, 2012.

Saavedra, Jorge, "Education financing developing countries: level and sources of funds" , The World Bank Press, Washington DC, 2002.

UNICEF, "A Human Right-Based Approach to Education for All: a Framework for the Realization of Children Right to Education and Right Within Education", United Nation Children's Fund, New York.

W. Jones, Phillip, "World Bank Financing of Education: Lending, Learning, and Development", Routledge, New York, 2007.

Wößmann, Ludger \& Erick. A Hanusek, "Education Quality and Economic Growth", The World Bank Publisher, Washington D.C, 2007. 


\section{Internet}

IMF, "History of Bretton Woods Agreement 1944; Cooperation and Recostruction (1944-71)”, Washington DC, 2008, pada https://www.imf.org/external/about/hist coop.htm, diakses pada 10 Agustus 2018.

PBB, "World Economic Situation and Prospect", 2012, pada http://www.un.org/en/development/desa I.../2012country_class.pdf , diakses pada 25 Nopember 2016

\section{Kamus}

Henry Campbell Black, “Black's Law

Dicitionary”, West Group, St. Paul, 1999 
